\title{
REQUEST OF THE EUROPEAN DEVELOPMENT AND GLOBALIZATION: THE PAYMENT BASED ON SHARES (IFRS 2)
}

\author{
Associate Professor PhD Gheorghe Lepădatu, „Dimitrie Cantemir” Christian University of \\ Bucharest, e-mail: cilezbujor@yahoo.com
}

\begin{abstract}
The share-based payment represents, for sure, a challenge for the business world in Romania and will certaintly gain ground. The initial acknowledgement is made in compliance with the rules provided in the General Frame for drawing up and presentation of the financial positions. In case that the payment is effected before the reception of the goods or services, the entity will acknowledge an advance payment granted. Depending on the manner in which the settlement will be done, the entity will acknowledge in counter-trade of the received goods or services either an increase of capital, or a debt. The problem of accounting the share options, especially those issued for the executive staff and for other employees of a company, in direct compensation for their efforts, has been disputed for a long time.
\end{abstract}

Keywords: balance sheet, opening IFRS, previous GAAP, shares, financial instruments, fair value

JEL codes: $M 41$

\section{The payment based on shares - a challenge for the business world}

At the beginning there was the payment in kind, followed by the payment with equivalent in kind, then the payment in money. From the point of view of the payment conditions, at the beginning there was the payment by the cash desk, then by card. All the forms were implemented with difficulty. The share-based payment represents, for sure, a challenge for the business world in Romania and will certaintly gain ground. The definition given by IFRS 2 to the transactions with share-based payment is the following: a transaction in which an entity acquires the goods or services by undertaking to transfer cash or other assets to the supplier of the goods or services for amounts which are based on the price (or value) of the entity's shares or other capital instruments of the entity [1].

According to IFRS 2, the share-based payments [2] can be:

a) settled by owner's equity, in which the entity receives goods or services as a counterperformance for the capital instruments of the entity (shares or options on shares);

b) cash settlement, in which the entity acquires by undertaking of debts towards the supplier of the goods or services for the amounts which are based on the price (or value) of the entity's shares or other capital instruments of the entity, and

c) settlement either in cash (or other assets), or by issue of capital instruments, at the option of the entity which receives the goods or services acquired or at the supplier's option.

Irrespective of the manner in which the transaction will be settled, the moment of acknowledgement is the same: the entity will acknowledge the goods or services received or acquired in a business deal with share-based payment when it obtains the goods or when the services are rendered [3]. If the goods or services acquired or received in a business deal with sharebased payment are not qualified for the acknowledgement as assets, they will be acknowledged as expenditure. The initial acknowledgement is made in compliance with the rules provided in the General Frame for drawing up and presentation of the financial positions. In case that the payment 
is effected before the reception of the goods or services, the entity will acknowledge an advance payment granted. Depending on the manner in which the settlement will be done, the entity will acknowledge in counter-trade of the received goods or services either an increase of capital, or a debt. The problem of accounting the share options, especially those issued for the executive staff and for other employees of a company, in direct compensation for their efforts, has been disputed for a long time [4].

No present-day IAS approaches this matter, but the project IASB regarding the share-based payment seems to produce a complete evaluation pattern on the basis of the fair value from among all the projects of the standardization bodies [5].

The fundamental problem in IAS/IFRS is the credibility of accounting. Under the circumstances in which, for the same year, a similar public company, in different countries, publishes different images of the sizes of the owner's equity and of the results, complying logically with the rules in force in those countries, the trust of the users of information will suffer [6].

\section{Share-based transactions with the employees or assimilated persons}

Lately, at international level, more and more companies started to grant their employees additional benefits in form of owner's equity securities issued either in form of additional compensations calculated on the basis of their own shares. This has several explanations, i.e.:

- In most of the countries, the taxation connected with salaries is perceived as burdensome and then the employers look for cheaper manners to pay the salaries

- Usually, the options granted to the employees are opposable to them either at the moment of performance, or of selling the securities acquired on their basis (the taxation is not effected at the moment of granting the options, as it is effected - for example - at the cash paid salary);

- The entity benefits from the deduction of at least a part of the committed salary expenditure;

- The granting of pensions in form of determined benefits ( a very often used manner at the beginning of the 20-th century) is considered to be very expensive for the company because of the evolution of several factors, such as: the growth of the duration of useful life, of the average salary etc.;

- It is an incentive factor for the employees (especially for managers), who must obtain performances in order to obtain the capital securities (Attention: the reverse side of the coin: sometimes managers are stimulated to report false performances, just to receive additional compensations !);

- It is a factor of making the staff faithful, taking into account that the employee must - as a rule - spend a certain number of years in the company in order to be entitled to benefits;

- The companies regard the issue of capital as a very cheap financing source and prefer to increase the number of issued shares instead of spending additional money on salaries.

\section{The Purposes of the Standard (IFRS 2- share-based payment)}

In order to guide the adoption, for the first time, of the international standards of financial reporting - whith regard to IFRS, the completion of the work at four projects of new-type standards was necessary, the first two as a result of the non-existence of a previous standard, capable to became a starting guide, and the other two, for the achievement of the target of convergence between the two big accounting systems with worldwide vocation - the international one (IFRS) and the AngloSaxon one (US-GAAP). IFRS 2 belongs to the category of standardization products regarding the 
new economic and accounting fields. An entity adopting the IFRS for the first time is encouraged, but not obliged to apply IFRS 2 - the share-based payment. All the international bodies appreciate that these IFRS must apply to all the transactions with share-based payment [7]. IFRS 2 is more comprehensive than the employees' share options, because it treats the issue of shares (and rights on shares) in exchange for some services and goods [8].

The national legislation established the categories of legal bodies which applied the provisions according to the European Norms, the period of accounting harmonization extending during the period 1999-2005 [9]. The main new aspects brought by these new legal regulations as compared to the Law no. 82/1991 and the Rules for application of this law refer especially to new concepts and targets, on the basis of which the information reported in the financial positions will be built.

The occurrence of two new documents [10] for the practice of accounting reporting in our country can be noticed, i.e.:

- " the status of the modification of the owner's equity" - which shows in detail the variations of the equity elements during the whole period of report, and

- "the status of the cash flow" - necessary to highlight the flow of earnings and payments during that period.

The annexes to the balance sheet have disappeared.

A series of new principles [11] appeared, such as:

- the principle of prevalence of the economic over the juridical aspect,

- the principle of the separate evaluation of the elements of assets and liabilities, and

- the principle of the significant importance.

The most important changes are those referring to the acknolwedgement and evaluation of the assets, respectively of the debts.

IFRS 2 requires that an entity should acknowledge the business deals with share-based payment in its financial positions, including the transactions with the employees or other parties which will be settled in cash, other assets or instruments of the entity's equity. There are no exceptions to this IFRS, others than those for the transactions for which other Standards are applied [12].

The category "members of the staff" comprises the employees of the entity and natural persons assimilated to the members of the staff, defined as "persons working for the enterprise, under its leadership, in the same manner as those persons would do, who would be legally and fiscally considered members of the staff", as follows:

the administrators non-employees:

- an individual who works under the direct supervision of the enterprise which receives the goods or service, irrespective of who his legal employer is,

- a certain individual, on whose performance a contract depends (example: data processing);

- an individual gives all the advantages to the work and to the enterprise, for a certain period of time;

- the individuals working on project basis in all the projects in which the enterprise bears the risk of non-performance;

- an individual who renders services similar to those mentioned by the members of the staff, the administrators.

From the practical point of view, the difference between the members of the staff - as they have been defined before - on the one hand, and the third parties who supply goods and services on the other hand, has incidence on the basis held for establishing the fair value (the fair value is the value of the instrument received by a member of the staff or assimilated to him); for third parties it is the value of the service performed or the delivered goods and also for the evaluation date in fair value. The remuneration may be immediate or deferred. The remuneration is deferred from the moment in which it is subject to the observance of conditions - such as: the attendance of the employee in the enterprise, during a minimal period of time. The employee is also obliged to 
observe the provisions of the Labour Code. It has been agreed upon to integrate the temporal variable in the analysis.

\section{The Evaluation of the Share-Based Payments [13]}

A difference must be made between:

a) the date of attribution :

- corresponds to the moment in which the contract is concluded between the enterprise and the other party;

- is the date on which the entity and the counter-party have a mutual agreement concerning the terms and conditions of the agreement. If this date is approved by the shareholders or by the Board of Directors, the attribution date corresponds to the date of approval by the competent body;

b) the date of acquirement of rights - from the practical point of view, the conditions of exercise are reached and the counter-party is free to exercise those rights;

c) the date of exercise - is the date on which the counter-party will effectively exercise those rights;

d) the date of evaluation - is not explicitly recognized by the standard; the term of "measurement" may be used - the date of evaluation is the date on which the value of the instrument, the service or the goods is measured. In case of direct evaluation it is the date of completion of the performance, which corresponds - most often to the date of acquirement of the rights. In case of the indirect evaluation it is the date of attribution [14].

Before being recorded in the books, the remunerations based on shares must be evaluated. The principles to be applied are distinct, depending if the counter-party is a member of the staff or a third party.

Regarding the transactions with "members of the staff", the principle is that of indirect evaluation. The number of issued instruments, futures, must be estimated, i.e. those instruments for which the entity waits to be acquired, then to be measured at their fair value on the date of attribution. Regarding the transactions with third parties, the principle is that of indirect evaluation of the performed service. The fair value of the performed services and delivered goods must be kept in mind, on the date on which the latter are effectively received by the entity (example: the fair value of the equity instruments on the date on which the services are received and the goods delivered shall be kept in mind).

The payment is also a civil juridical act that materializes the agreement between the person who makes the payment (solvens) and the person who receives it (accipiens) having as an immediate cause the intention to pay off an obligation (animo solvendi) by performing the service owed by the debtor to the creditor. The payment must be made to the creditor, his representative or to the person authorized by the law or the court of law to receive it. The exigencies of business activity have imposed the settlement of special rules regarding the price in the commercial obligations. These rules refer to the establishment of the price and the currency of payment. If on the conclusion of commercial contracts the parties did not establish the price but had in mind the real price or the current price, this will be the price in the lists of the stock exchange of the place where the contract has been concluded, respectively of the nearest place.

The share-based payment - IFRS 2- is not compulsory for the entities that have passed to IFRS, and if such a payment is used, it is necessary that previously it should be appropriately established by norms at internal level. Pursuant to the provisions of the Law no. 31/1990, re-issued, in the joint stock company the registered capital is represented by shares issued by the company, which, as per manner of transmission may be registered shares or bearer shares. The shares issued 
by a joint stock company as a result of a subscription by public offer of marketable securities are subject to the rules applicable to the organized market on which those shares are marketed.

The term "share" has several meanings:

- it is a fraction of the registered capital - it must compulsorily be equal to the other shares; the law provides a minimum ceiling regarding the nominal value of the share, which means that the company may issue shares with a higher nominal value,

- it is a security - it contains and establishes the rights and obligations arising from the capacity of shareholder,

- it designates the relation within the company, i.e. the legal relation between shareholder and company.

The characteristics of the shares:

- they are fractions of the registered capital that have a certain nominal value

- they are equal fractions of the registered capital,

- the shares are indivisible,

- they are negotiable securities - the shares issued by the company are securities which incorporate certain property values, therefore they are considered securities or credit securities and are called marketable securities.

It has been noticed that the shares do not completely fulfill the conditions of the credit securities; the shares represent securities which incorporate certain rights, but they do not fulfill the conditions of autonomy and literalness. Thus, the shares are not autonomous securities, independent of the juridical act from which they derive, they arise from the company contracts. At the same time, in case of assignment of shares, the person who acquires them becomes the holder of a derived right, and not of a new, initial right. In order to enable the performance of share-based payments, appropriate modifications of the law must be made.

The shares are securities without literalness, the extent of the rights conferred is incompletely established by the security, reason for which the memorandums of association must be checked.

Because they have not all the characteristics of the credit securities, it is considered that they are not perfect credit securities, but special securities, called corporate, associate or participation securities.

The target of IFRS 2 is represented by the specification of the financial reporting by an entity when it performs a transaction with share-based payment, which requires that an entity should reflect in its profit, or in loss, its financial position, the effects of the share-based deals, including the expenses associated to the transactions in which options on shares are granted to the employees.

\section{The Area of Applicability [15]}

At the level of the European Union, the entities which quote and those which consolidate the financial positions must apply the IAS / IFRS. Some countires have applied quantitative criteria of "size". It is the principle of public responsibility, which should divide the enterprises into two categories, that gains more and more ground:

- enterprises with public responsibility - those who must apply complete IFRS;

- the other enterprises that should apply another set of standards - those specific for the small and medium-size enterprises.

IFRS is a model of Anglo-Saxon financial reporting and is orientated towards the capital market.

a) The acces to the international standards

There are three manners of acces to the application of IFRS: 
1. the adoption of the IFRS as such - the ideal manner - which presumes difficulties connected with different cultures and traditional values, juridical systems which are different from the origine of law of IFRS, but also with the acceptance of the priority of the principles which have to replace the traditional national rules;

2. the working out of national standards based on the principles stipulated in IFRS;

3. the adaptation of the IFRS to the specific national .character.

b) Factors that influence the implementation of IFRS

Among the factors that influence the implementation of IFRS, the following are worth mentioning:

- $\quad$ the principles - standards must be based on principles and not on detailed rules, as it is known that "by detailed rules a chance is given to the infringement of the law", complexity - the more sophisticated the IFRS become, it seems that they do not represent the best solution for all the enterprises.

c) the application of IFRS in Romania

In order to establish the enterprises which apply these rules, the standardization body used the quantitative criterion referring to:

- the turnover - at least 7.3 million EURO,

- total assets - a volume of at least 3.65 million EURO and

- number of employees - at least 50 employees.

According to Romania's calendar, starting with the year 2006 only those enterprises that had on the $31^{\text {-st }}$ December 2005 a turnover under 7.3 million EURO, a volume of assets under 3.65 million EURO and under 50 employees remained outside the application programme of these rules.

The final standard IFRS 2 - payments assimilated in shares, including those assimilated within the saving plans of the company, provides as a general principle that the granting of equity instruments to remunerate goods or services obtained or which are going to be obtained, which must be evaluated at their fair value and recorded as expenditure - as they are consumed; the counterparty in accounting formula is represented by the equity or the debts - in some particular cases.

The standard IFRS 2 provides many details regarding the ways of establishing the fair value of the acquired goods and services [16].

The registration of an expenditure in the books (or of an asset, according to the circumstances), to reflect the fair value of the obtained goods and services, will create a major discrepancy for the financial positions.

The provisions that do not appear in form of discrepancies [17] refer to:

- establishing the fair value of the received goods and services, paid for by equity instruments;

- the manner of application of the general principle of bookkeeping in some particulare situations;

- processing the payment transactions assimilated in shares, completed by the payment of liquidity;

- processing the payment transactions assimilated in shares, which allow the choice of the manner of settlement (liquidity or equity instruments), either with the issuer, or with the beneficiary.

The entity shall apply IFRS 2 in registering all the transactions with share-based payment (the opening balance sheet IFRS is the border point between the national accounting policies and practice and IFRS), and provides the evaluation principles and specific requirements for the following transactions:

- the transactions with share-based payment with settlement in equity instruments of the entitythe entity receives the goods and services as counter-value for the equity instruments; 
- the transactions with share-based payment with settlement in cash - the entity acquires goods and services by undertaking debts towards the suppliers of those goods or services, whose amount is based on the price of the shares or of other equity instruments;

- Transactions in which the entity receives or acquires goods or services, and the terms of the agreement allow either the entiy or the supplier of those goods or services the choice of the manner of settlement in cash - or other assets, or by issuing of equity instruments.

\section{Acknowledgement. Elements Regarding the Payments Assimilated in Shares [18]}

An entity will acknowledge the goods or services received or acquired by a transaction with share-based payment when it obtains the goods or when the services are performed. The entity will acknowledge a corresponding growth of its equity if the goods or services have been received in a transaction with share-based payment with settlement in equity instruments of the entity, or a debt if the goods or services have been acquired in a transaction with share-based payment with settlement in cash. When the goods or services received or acquired in a transaction with share-based payment are not qualified for acknowledgement as assets, they shall be acknowledged as expenses.

The expenditure derives from the consumption of goods or services - the services are generally consumed immediately, in which case the expenses are acknowledged by the partner who performs the services. The goods can be consumed during a period of time or, in case of stocks sold at a subsequent date, in which case the expenditure is acknolwledged when the goods are consumed or sold.

Sometimes it is necessary for an expenditure to be acknowledged before the goods or services have been consumed or sold, because the latter do not qualify for the acknowledgement as assets (example: an entity may acquire goods as part of the research stage of a project for the development of a new product). Although those goods have not been consumed, they can be in the position of not meeting the conditions for the acknowledgement as assets according to the applicable IFRS.

We can conclude that IFRS 2 belongs to the category of the standardizing products concerning the new economic and accounting fields. An entity which adopts the IFRS for the first time is encouraged, but not obliged to apply IFRS 2 - the share-based payment. All the international bodies appreciate that these IFRS must be applied to all the transactions with share-based payment. The IFRS 2 are more comprehensive than the options on shares of the employees because they treat the issue of shares (and rights on shares) in exchange for services and goods.

\section{References}

1. International Financial Reporting Standards $\left(\operatorname{IFRS}_{s}{ }^{\circledR}\right)$ including the International Accounting Standards $\left(I A S_{S}^{\circledR}\right)$ and their constructions on the 1-st January 2007, 3-rd revised edition, Bucharest, Publishing House CECCAR 2007, p 181.

2. Ibidem.

3. Ibid., p 182.

4. Barry J. Epstein, Abbas Ali Mirza - WILEY IFRS 2005: "Interpretarea şi aplicarea Standardelor Internaționale de Contabilitate şi Raportare Financiară - Interpretation and Application of the International Accounting and Financial Reporting Standards", Publishing House Bucharest ,2005, p. 695.

5. Ibidem.

6. Feleagă N. - Sisteme contabile comparate, 2-nd edition, Vol. I, Contabilitățile anglosaxone Economic Publishing Hous, Bucharest, 1999, p. 18.

7. Hennie van Greuning - International Financial Reporting Standards, A practical guide, The World Bank, revised edition 2007, Institute IRECSON, Bucharest, 2007, p 163. 
8. Ibidem.

9. Ordinance of the Ministry of Public Finances no. 907/27 June 2005, regarding the approval of the categories of legal bodies which apply the accounting rules according to the International Financial Reporting Standards, respectively accounting rules according to the European Norms, published in the Offical Journal of Romania, Part I, no. 597/11.07.2005.

10. Boajă M., Lepădatu Ghe. - Standardele Internationale de Raportare Financiară (I.F.R.S.), Noțiuni fundamentale, Publishing House Cermaprint, Bucharest, 2006, page 78.

11. Ristea M. - Metode şi politici contabile de intreprindere, Publishing House Tribuna Economica, Bucharest, 2000, p 38.

12. International Financial Reporting Standards $\left(I F R S_{s}^{\circledR}\right)$ including the International Accounting Standards $\left(I A S_{S}{ }^{\circledR}\right)$ and their construction on the $1^{- \text {st }}$ January 2007, 3-rd revised edition, Bucharest, Publishing House CECCAR 2007, p182.

13. International Financial Reporting Standards (IFRS $\left.{ }_{s}^{\circledR}\right)$ including the International

14. Accounting Standards $\left(I A S_{s}^{\circledR}\right)$ and their construction on the $1^{\text {-st }}$ January 2007, 3-rd revised edition, Bucharest, Publishing House CECCAR 2007, p 226.

14. Ibid., p 227.

15. International Financial Reporting Standards $\left(\operatorname{IFRS}_{s}^{\circledR}\right)$ including the International

16. Accounting Standards $\left(I A S_{s}^{\circledR}\right)$ and their construction on the $1^{- \text {st }}$ January 2007, 3-rd revised edition, Buchares, Publishing House CECCAR 2007, p 214.

17. International Financial Reporting Standards $\left(I F R S_{s}^{\circledR}\right)$ including the International Accounting Standards $\left(I A S_{s}^{\circledR}\right)$ and their construction on the $1^{- \text {-st }}$ January 2007, 3-rd revised edition, Bucharest Publishing House CECCAR 2007, p. 230.

18.. Ibidem

19. Hennie van Greuning, International Financial Reporting Standards, A practical guide, The World Bank, revised edition 2007, Institute IRECSON, Bucharest, 2007, p. 165. 